\title{
RESPON EKOLOGIS DAN KREATIF BEBAN LIMBAH FURNITUR RUSAK DI INSTITUSI PENDIDIKAN
}

\author{
Monika Evelin ${ }^{1}$, Feliecia Angelina ${ }^{2}$, Yusita Kusumarini ${ }^{3 *}$ \\ 1,2,3 Program Studi Desain Interior, Fakultas Seni dan Desain, Universitas Kristen Petra \\ Jl. Siwalankerto 121-131, Surabaya 60236 \\ *Penulis korespondensi; email: yusita@peter.petra.ac.id
}

\begin{abstract}
Abstrak: Limbah furnitur rusak di institusi pendidikan adalah permasalahan rutin yang cukup menjadi beban bagi pengelola sarana prasarana di institusi pendidikan. Sebagai studi kasus dalam bahasan ini adalah menumpuknya furnitur rusak di Universitas Kristen Petra.Isu tersebut menjadi materi kasus yang dipilih dan perlu diselesaikan dalam mata kuliah EkoDesain Program Studi Desain Interior, Universitas Kristen Petra pada tahun 2018. Fenomena menumpuknya furnitur rusak di gudang UPPK (Unit Pemeliharaan dan Pelayanan Kampus) dipandang sebagai bagian dari permasalahan lingkungan kampus yang perlu diresponi secara ekologis dan kreatif. Respon terhadap permasalahan tersebut diproseskan dalam kegiatan pembelajaran dengan melibatkan mahasiswa dan pemangku kepentingan, dengan pendekatan design thinking dan metode service-learning. Hasil dari proses pembelajaran tersebut adalah 21 produk kreatif berupa furnitur baru untuk memenuhi kebutuhan aktivitas di kampus.
\end{abstract}

Kata kunci: Respon ekologis-kreatif; service learning; design thinking.

\begin{abstract}
Ex-furniture waste in educational institutions is a routine problem that is quite a burden on infrastructure managers in educational institutions. As a case study in this discussion is the accumulation of ex.furniture at Petra Christian University. The issue becomes the case material chosen and needs to be resolved in the Eco-Design course in Interior Design Study Program, Petra Christian University in 2018. The phenomenon of the accumulation of ex.furniture in UPPK (Campus Maintenance and Services Unit) warehouse is seen as part of campus environment problems that need to be responded ecologically and creatively. Responses to these problems are processed in learning activities involving students and stakeholders, with design thinking approaches and service-learning methods. The results of the learning process are 21 creative products in the form of new furniture to meet the activity needs on campus.
\end{abstract}

Keywords: Ecological-creative response; service learning; design thinking.

\section{PENDAHULUAN}

Sejak 2010, isu permasalahan lingkungan semakin mengkhawatirkan seluruh pihak, mulai dari berkurangnya lahan hijau, polusi dan pencemaran, krisis lingkungan global, berkurangnya sumber daya alam, dan rusaknya ekosistem serta terancamnya keragaman hayati. Oleh karena itu, muncul gerakkan yang dinamakan Go-Green, gerakan ini membuat banyak orang sadar dan mulai gencar mengkampanyekan dan mensosialisasikan GoGreen dalam berbagai aktivitas diantaranya reboisasi, car free day, mengolah sampah menjadi produk, dan sebagainya. Tidak hanya melalui aktivitas tersebut, namun penerapan Go-Green telah masuk keberbagai bidang mulai dari proses produksi hingga distribusi, dan dapat diolah kembali yang sifat berkelanjutan. Adapun terdapat $4 \mathrm{R}$ yang menjadi konsep utama dari Go- Green yaitu reduce, reuse, recycle, dan replace.

Salah satu pembelajarandi mata kuliah EkoDesain, Prodi Desain Interior di Universitas Kristen
Petra tahun 2018, mengajak para mahasiswa untuk memahami isu lingkungan yang berhubungan dengan go-green, seperti halnya terjadi penumpukan ex-perabot yang tidak terpakai lagi di gudang perbekalan UPPK. Dari latar belakang tersebut, masalah yang dapat dijabarkan sebagai berikut:

1. Bagaimana mata kuliah Eko-Desain merespon keadaan yang riil terkait masalah ex-perabot kampus?

2. Bagaimana solusi kreatif yang dihasilkan dari proses pembelajaran mata kuliah Eko-Desain 2018 ?

3. Pembelajaran apa yang didapat dari proses kegiatan service learning mata kuliah Eko-Desain 2018 ?

\section{METODE PELAKSANAAN}

Mata Kuliah Eko-Desain mengajarkan mahasiswa untuk dapat memahami teori sustainable design yang menjadi dasar dalam penerapan ilmu eko-desain. 
Eko-desain adalah ilmu yang mempelajari isuisu yang terjadi di lingkungan dengan menitikberatkan hubungan desain terhadap kepentingan dan keberlangsungan lingkungan hidup dan manusia [1], dari permasalahan isu tersebut perlu adanya solusi yang dapat mengurangi atau mengatasi. Dalam waktu yang dekat ini terdapat isu bahwa kurang adanya sikap kepedulian terhadap lingkungan yang ditunjukkan oleh masyarakat. Masyarakat hanya bersikap mengikuti trend tanpa adanya pemahaman yang benar akan sustainable design, bahkan terkadang seorang desainer pun kurang dapat memahami sustainable design ini. Maka, eko-desain memiliki beberapa aspek yang perludipelajari dan diperhatikan oleh para desainer interior dalam membuat desainnya menjadi sustainable design yang mana dapat dipertanggungjawabkan oleh desainer. Untuk itu, tujuan dari Mata Kuliah Eko-Desain adalah mengajak mahasiswa dapat mempelajari permasalahan yang ada di lingkungan kampus yang berkaitan dengan eko-desain dan mencari solusi dari permasalahan tersebut dengan memperhatikan aspek-aspek yang ada dan menerapkannya dalam desainnya serta bertanggung jawab akan hasil dari solusi kreatif desain tersebut.

Pemahaman eko-desain dapat diterapkan dalam interior bangunan dan produk, yang terbagi menjadi dua macam yaitu, eko-interior dan ekoproduk. Eko-interior berarti berkaitan dengan hubungan timbal-balik antara manusia sebagai pengguna dengan lingkungan dalam bangunan. Sebagai desainer berarti berkaitan dengan keputusan desain yang memperhatikan isu/kondisi lingkungan luar suatu ruang. Eko-interior ini diterapkan dalam delapan aspek yang berhubungan dengan interior suatu bangunan yaitu antara lain organisasi ruang, pemilihan material, sistem pencahayaan, sistem penghawaan, sanitasi air, polusi dalam ruang, emisi elektromagnetik, manajemen sampah dalam ruang [4]. Sedangkan untuk ekoproduk aspek-aspek yang perlu diperhatikan dalam strategi ekologis desain produk, diuraikan dalam lima fase daur hidup produk, yaitu [2]:

1. Pre-Production

Persiapan sebelum produksi dalam hal segi desain, pemilihan material, produk yang berkelanjutan.

2. Manufacturing / making / fabrication

Dalam hal ini mempertimbangkan proses produksi dari segi pemakaian material yang meminimalisir sisa buangan (siklus kontinyu), substansi yang mengganggu kesehatan manusia dan kehidupan ekosistem, dan tercapainya costeffective.

3. Distribution/transportation

Mempertimbangkan dalam segi packaging yang bentuknya flat untuk efisiensi transportasi dan penyimpanan, desain produk yang dapat dikonstruksikan dengan mudah oleh konsumen [2].

4. Functionality and Use

"Design is not just what it looks like, design is how it works." - Steve Jobs.

\section{Disposal}

Mempertimbangkan produk yang dapat dimanfaatkan dan diproses kembali, sehingga meminimalisir pembuangan yang susah diurai ke dalam tanah.

Supaya mahasiswa lebih memahami teori ekoproduk, maka Mata Kuliah Eko-Desain mengajak mahasiswa untuk menjawab tantangan dengan memberikan solusi kreatif dalam mengolah experabot kampus menjadi eko-produk yang sustainable sebagai bentuk terapan teori eko-produk. Metode kegiatan yang diterapkan adalah pendekatan service learning dan design thinking. Metode pendekatan service learning adalah kegiatan berinteraksi secara langsung antara mahasiswa dengan mitra kampus untuk dapat mengetahui kebutuhan yang diperlukan. Service Learning menurut para ahli adalah sebagai berikut [3]:

Menurut Mauris (2010), service learning merupakan cara mengajar dan belajar yang menghubungkan tindakan positif dan bermakna di masyarakat dengan pembelajaran akademik, perkembangan pribadi dan tanggung jawab sebagai warga masyarakat.

Menurut Furco dkk. (2001) dalam The Essence of the Pedagogy, service learning merupakan pelayanan kepada masyarakat berbasis kurikulum yang mengintegrasikan pembelajaran di dalam kelas dengan aktivitas melayani masyarakat.

Jacoby dkk. (2013) dalam Building Partnerships for Service Learning, adalah suatu bentuk pendidikan tentang pengalaman dimana peserta didik terlibat dalam kegiatan yang menyangkut manusia dan kebutuhan masyarakat dengan kesempatan yang sengaja direncanakan untuk meningkatkan perkembangan dan pembelajaran peserta didik.

Bringle dkk. (2005) service learning: Intercommunity \& Interdisciplinary Explorations, service learning sebagai pengalaman dalam pendidikan berbasis mata pelajaran yang memiliki kredit dimana peserta didik dalam kegiatan melayani kebutuhan masyarakat yang sudah diidentifikasi serta melakukan refleksi terkait kegiatan service learning yang telah dilaksanakan secara mendalam dan memiliki apresiasi luas tentang disiplin serta rasa tanggung jawab sebagai warga masyarakat.

Dari beberapa definisi menurut para ahli diatas, maka service learning merupakan strategi belajar-mengajar yang memberi pengalaman menyangkut implementasi akan teori melayani masyarakat dan kebutuhannya dengan disiplin dan memiliki rasa tanggung jawab serta dapat merefleksikan secara mendalam.

Metode lain yang mendukung mahasiswa untuk dapat mengetahui kebutuhan yang diperlukan serta solusi yang dapat dimunculkan adalah metode design thinking. Metode ini bertujuan untuk mendapatkan solusi kreatif dari permasalahan menumpuknya ex-perabot di gudang perbekalan dan sekaligus menjawab kebutuhan mitra kampus. Adapun tahapan-tahapan dalam design thinking 
yang digunakan ialah eksplorasi mitra kampus, eksplorasi material ex-perabot, ideasi, realisasi produk, evaluasi, dan refleksi dari mahasiswa serta mitra UPPK.

Kegiatan service learning Mata Kuliah EkoDesain 2018 diadakan pada tanggal 19 Februari 2018 sampai 4 Juli 2018.

\section{PELAKSANAAN KEGIATAN}

Pembuatan produk yang dapat menjawab masalah penumpukan ex-perabot ini memerlukan tahapan-tahapan yang harus dilakukan secara sadar dan tidak sadar. Tahapan-tahapan itu adalah eksplorasi mitra kampus, eksplorasi material experabot, ideasi, realisasi produk, evaluasi, serta refleksi.

\section{Eksplorasi Kebutuhan Mitra Kampus}

Dalam kegiatan service learning Mata Kuliah Eko-Desain, mahasiswa mendapatkan pemahaman secara teori terlebih dahulu, setelah itu mahasiswa diajak untuk berempati akan kebutuhan mitra kampus yang belum terpenuhi dengan cara mahasiswa dianjurkan untuk berinteraksi langsung. Maka, metode yang dilakukan adalah wawancara dan observasi mitra kampus Universitas Kristen Petra. Hasil wawancara dan observasi merupakan data yang dapat berupa bentuk foto dan catatan.

Pengumpulan data hasil dari wawancara dan observasi tersebut bertujuan untuk menemukan masalah kebutuhan mitra kampus, yang mana mahasiswa harus melakukan analisa terhadap data yang telah dikumpulkan.

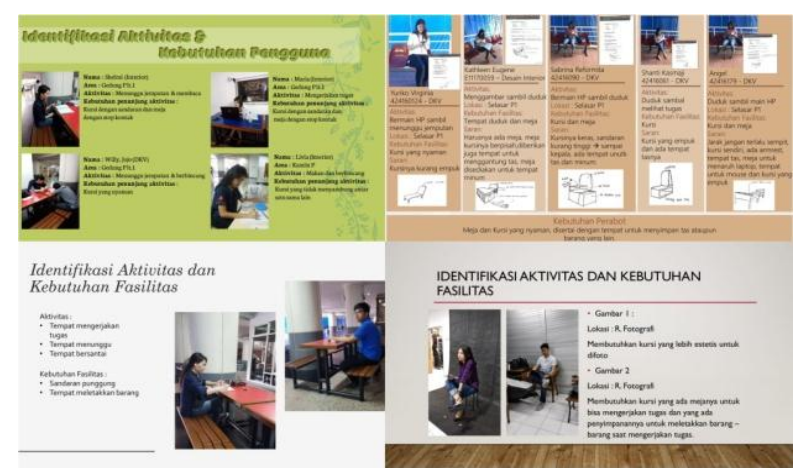

Gambar 1. Beberapa tahap dokumentasi eksplorasi

\section{Eksplorasi Karakteristik Ex. Perabot Kampus}

Setelah mahasiswa melakukan tahap wawancara dan observasi di kampus, mahasiswa dapat melakukan eksplorasi karakteristik ex.perabot di UPPK. Tujuan dari eksplorasi ini adalah menentukan ex-perabot mana yang bisa digunakan atau disesuaikan dengan solusi kreatif yang ekologis. Untuk urusan pengambilan barang ex-perabot tersebut, mahasiswa harus melakukan konsultasi terlebih dahulu dengan mitra UPPK supaya mahasiswa dapat memahami jenis dan potensi untuk diolah sesuai dengan solusi kreatifnya.

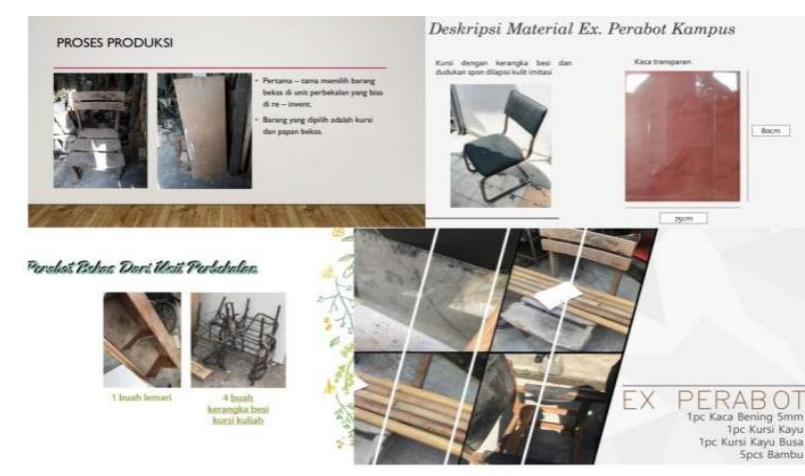

Gambar 2. Ex-perabot pilihan beberapa kelompok

\section{Menemukan dan Mendiskusikan Ide Awal}

\section{Solusi Produk Kreatif}

Ide yang dikreasikan oleh mahasiswa diperoleh dari informasi kebutuhan fasilitas ruang bagi civitas pengguna ruang sekitar kampus (utamanya di Gedung P) serta UPPK. Hasil diskusi ditransformasikan ke dalam gagasan ide solusi kreatif dari sebelumnya ex-perabot menjadi perabot yang berfungsi kembali sesuai dengan kebutuhan mitra kampus. Gagasan ide solusi kreatif ini diwujudkan dalam bentuk sketsa terlebih dahulu. Lalu dari hasil sketsa-sketsa ide desain yang ada, didiskusikan dan dianalisa bersama mitra civitas kampus (pengguna ruang dan UPPK), apakah ide solusi kreatif yang dikemukakan sudah menjawab dari permasalahan dan kebutuhan yang ada. Jika solusi kreatif desainnya belum maksimal, maka harus dilakukan pengembangan desain dan didiskusikan kembali untuk bisa mencapai target solusi kreatif yang menjawab kebutuhan mitra kampus tersebut.

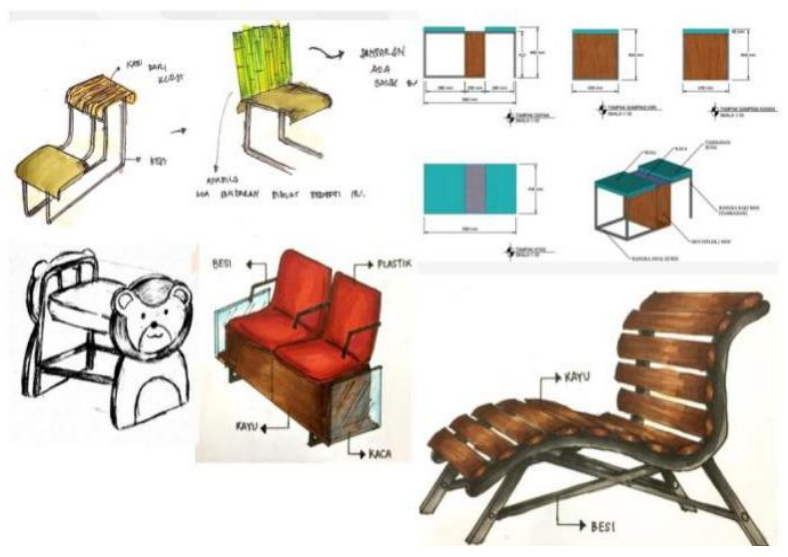

Gambar 3. Beberapa hasil sketsa ideasi

\section{Realisasi Produk}

Setelah ditemukannya solusi kreatif desain terbaik dari segi pemecahan masalah yang diambil, maka ide tersebut direalisasikan dengan bantuan laboratorium material di kampus maupun di bengkel-bengkel kerja di luar kampus.

Berikut adalah data hasil produk ekologis kreatif dari proses pembelajaran Mata Kuliah EkoDesain yang telah selesai direalisasikan: 
Tabel 1. Data Hasil Produk dari Mata Kuliah Eko Desain Kegiatan Service Learning

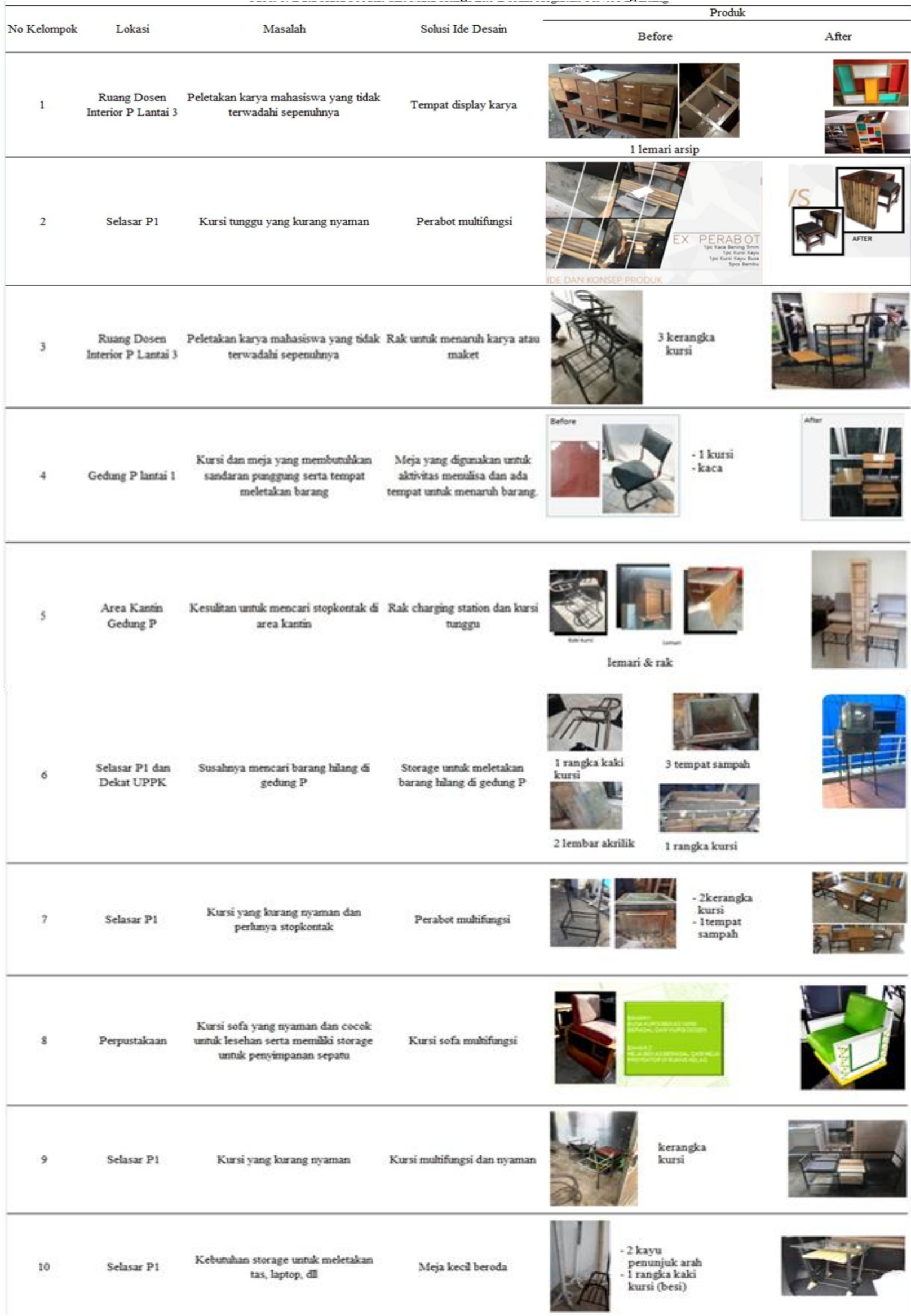




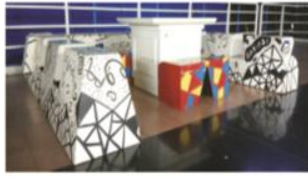

Perabot multifungsi
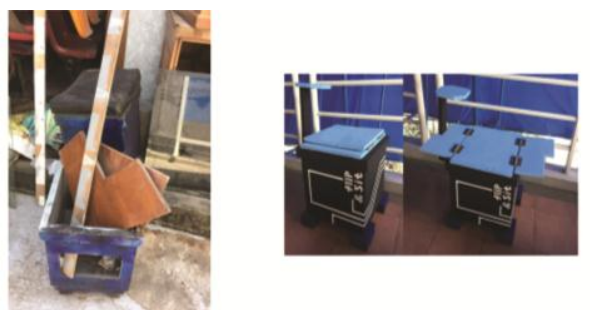

Kurang nyaman dan aman untuk digunakan
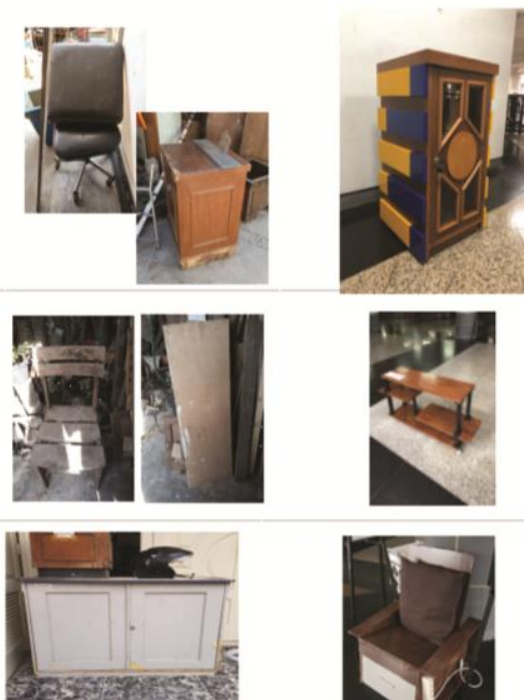
dan laptop.

$\begin{array}{cc}\text { - Kesusahan meletakkan barang } & \cdot \text { Storage kecil untuk menyimpan } \\ \text { bawaan yang banyak } & \text { buku - buku } \\ \text { - Tempat duduk yang kurang } & \cdot \text { Kursi yang nyaman } \\ \begin{array}{c}\text { nyaman ketika menunggu kelas } \\ \text { - Berebut meja dan kursi dengan } \\ \text { stop kontak }\end{array} & \text { - Stop kontak untuk mengecas } \\ \text { alektronik seperti handphone } \\ \text { dan laptop. }\end{array}$

Meringankan beban pengasuh ketika menidurkan anak

Kursi yang seperti ayunan basement $T$ sehingga tidak perlu selalu berdiri.
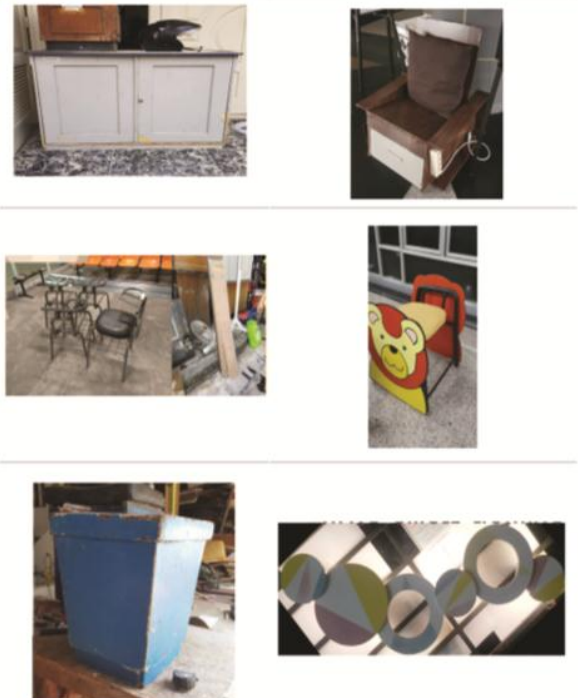

Kesulitan membawa karya dan

17 Gedung P It. 3 barang pribadi ketika pengumpulan Perabot multifungsi (trolley dan tugas

meja)

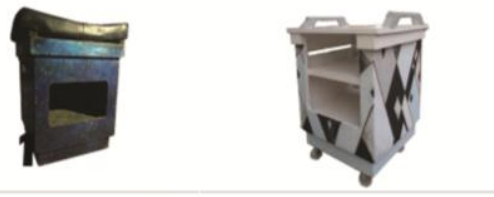

18

Gedung $P$

Kurangnya storage untuk meletakkan gambar dan kertas-

Rak ambalan
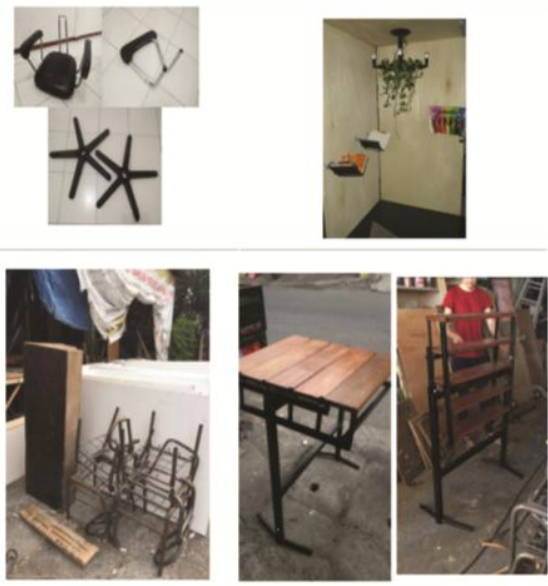


\section{Evaluasi Karya Eko-Produk}

Evaluasi karya eko-produk ini dilakukan dengan adanya pameran hasil realisasi produk untuk dapat diuji cobakan oleh mitra yang berdasarkan apakah kebutuhan dan fungsi pada produk yang direalisasikan sudah terpenuhi secara maksimal. Berikut adalah tabel evaluasi eko-produk berdasarkan penilaian mitra dan dosen:

Tabel 2. Analisis Evaluasi Karya Eko-Produk

\begin{tabular}{|c|c|c|c|}
\hline \multirow{2}{*}{$\begin{array}{l}\text { No. } \\
\text { Klmpk }\end{array}$} & \multirow[b]{2}{*}{ Nama Produk } & \multicolumn{2}{|c|}{ Analisis Eko-Produk } \\
\hline & & $\begin{array}{l}\text { Memenuhi } \\
\text { Kebutuhan }\end{array}$ & Fungsi \\
\hline 1 & $1+1-$ (Cabinet) & $\mathrm{v}$ & $\mathrm{v}$ \\
\hline 2 & Stul Va Stol - (Meja Kursi Bambu) & $\mathrm{v}$ & $\mathrm{v}$ \\
\hline 3 & Iron Shelf - (Rak Susun) & $\mathrm{v}$ & $\mathrm{v}$ \\
\hline 4 & Iwood TC - (Kursi) & $\mathrm{v}$ & $\mathrm{v}$ \\
\hline 5 & Charging Station & $\mathrm{v}$ & $\mathrm{v}$ \\
\hline 6 & TI Box - (Lemari) & $\mathrm{x}$ & $\mathrm{x}$ \\
\hline 7 & Modular Bench - (Kursi dan Meja) & $\mathrm{v}$ & $\mathrm{v}$ \\
\hline 8 & Evergreen - (Kursi) & $\mathrm{x}$ & $\mathrm{v}$ \\
\hline 9 & Double Comfort - (Kursi dan Meja) & $\mathrm{v}$ & $\mathrm{v}$ \\
\hline 10 & H-Table - (Meja Kaca) & $\mathrm{v}$ & $\mathrm{v}$ \\
\hline 11 & Flip and Slip - (Kursi) & $\mathrm{x}$ & $\mathrm{v}$ \\
\hline 12 & Re-Bllow - (Lemari Dispenser) & $\mathrm{v}$ & $\mathrm{v}$ \\
\hline 13 & Shoes Corner - (Rak Sepatu) & $\mathrm{v}$ & $\mathrm{v}$ \\
\hline 14 & Eco Relaxing Chair - (Kursi) & $\mathrm{x}$ & $\mathrm{x}$ \\
\hline 15 & Dedeq Boboq - (Kursi Goyang) & $\mathrm{v}$ & $\mathrm{v}$ \\
\hline 16 & Wave Circle Lighting - (Lampu Dinding) & $\mathrm{x}$ & $\mathrm{v}$ \\
\hline 17 & 3 Shelf Trolley & $\mathrm{x}$ & $\mathrm{v}$ \\
\hline 18 & Floating Invention - (Lampu dan Rak Dinding) & $\mathrm{x}$ & $\mathrm{v}$ \\
\hline 19 & Rack-Able - (Rak Display) & $\mathrm{x}$ & $\mathrm{v}$ \\
\hline 20 & Functional Trolley - (Trolly) & $\mathrm{v}$ & $\mathrm{v}$ \\
\hline 21 & Garden Ngadeg - (Rak Bunga) & $\mathrm{x}$ & $\mathrm{v}$ \\
\hline
\end{tabular}

Ringkasan hasil evaluasinya adalah sebagi berikut:

1. Sebelas (11) produk optimal dalam memenuhi kebutuhan dan fungsi, yaitu;

- Kelompok 1, Cabinet

- Kelompok 2, Meja Kursi Bambu

- Kelompok 3, Rak Susun

- Kelompok 4, Meja \& Kursi

- Kelompok 5, Charging Station

- Kelompok 7, Kursi

- Kelompok 9, Kursi Panjang

- Kelompok 10, Meja Kaca

- Kelompok 12, Rak Dispenser

- Kelompok 13, Rak Sepatu

- Kelompok 15, Baby Sitting Chair

- Kelompok 20, Trolly

2. Tujuh (7) produk yang cukup dalam memenuhi kebutuhan dan fungsi, yaitu;

- Kelompok 8, Kursi

- Kelompok 11, Flip and Slip (kursi)

- Kelompok 16, Lampu Dinding

- Kelompok 17, Shelf Trolly

- Kelompok 18, Lampu dan Rak

- Kelompok 19, Rak Display

- Kelompok 21, Rak Bunga

3. Dua (2) produk yang tidak memenuhi kebutuhan dan fungsi,yaitu;

- Kelompok 6, TI Box (storage)

- Kelompok 14, Kursi
Berikut adalah sebagian dokumentasi pada saat pameran sekaligus uji fungsi furnitur baru hasil kreatifitas ekologis dari Mata Kuliah EkoDesain 2018:

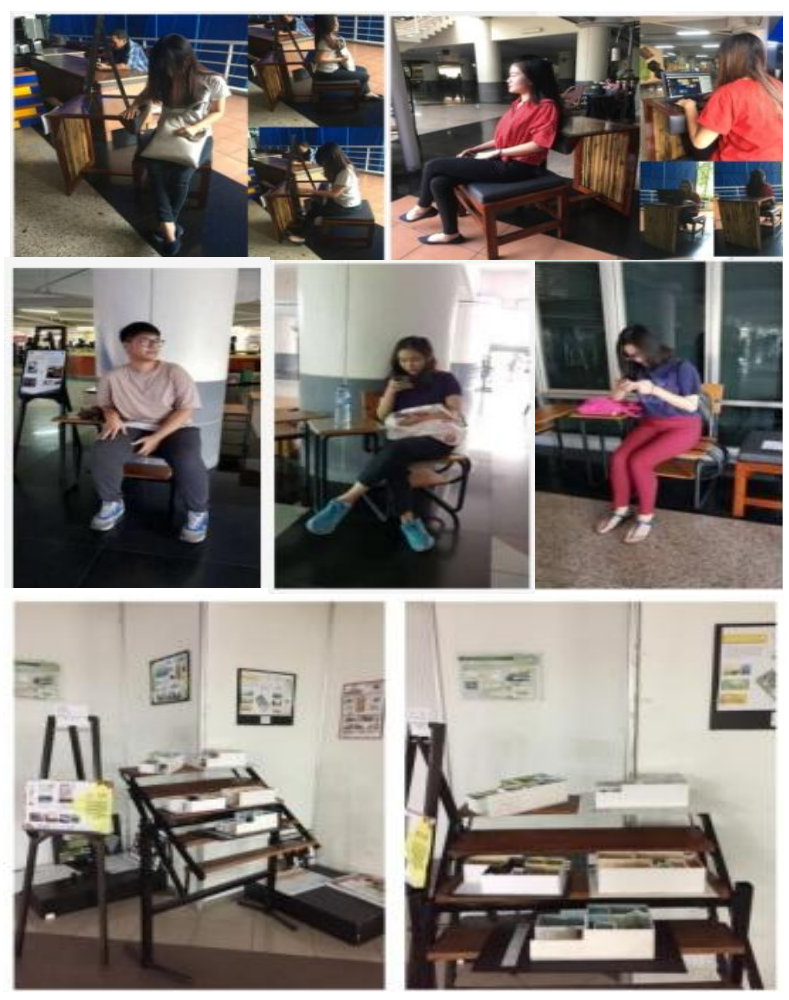

Gambar 4. Sebagian dokumentasi pameran evaluasi karya produk

\section{REFLEKSI OLEH MAHASISWA DAN MITRA KAMPUS}

Refleksi ini bertujuan untuk mengambil pembelajaran apa yang didapat dari kegiatan service learning yang telah dilakukan di Mata Kuliah EkoDesain 2018.

Berikut beberapa hasil refleksi mahasiswa Mata Kuliah Eko-Desain sebagai pelaku pelaksana service learning ini:

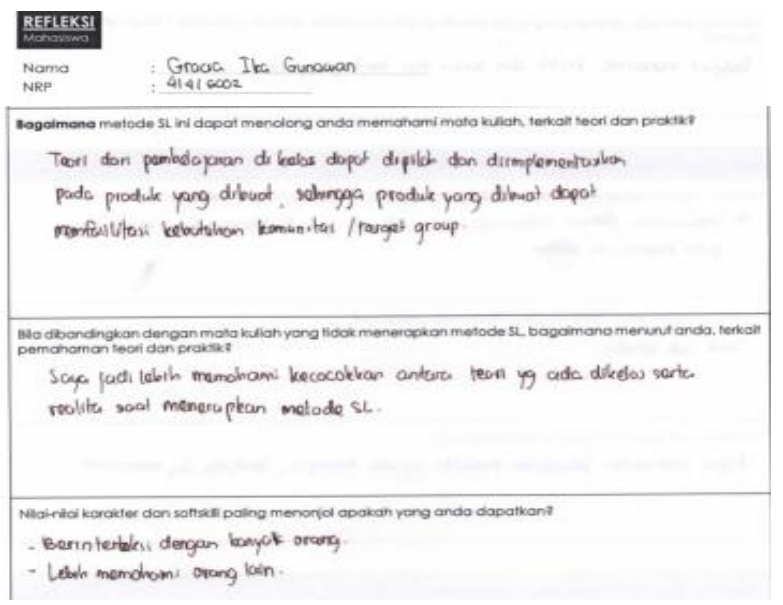

Gambar 5. Salah satu refleksi dari mahasiswa Mata Kuliah Eko-Desain 
Dari beberapa mahasiswa Mata Kuliah EkoDesain berpendapat bahwa kegiatan service learning yang dilakukan ini, membuat para mahasiswa lebih mudah untuk memahami akan teori ekodesain terutama eko-produk dikarenakan langsung mempraktekkan ke lapangan dengan tahapan seperti berinteraksi langsung dengan mitra UPPK, mitra kampus, dan tukang, membuat produk yang dapat menjawab kebutuhan mitra, dan sebagainya. Tidak hanya hard-skill yang tercapai dalam proses pembelajaran ini, namun soft-skill juga.

Selanjutnya, berikut adalah beberapa refleksi dari mitra UPPK dan Wakil Rektor 2 sebagai mitra kerjasama dengan Mata Kuliah Eko-Desain:

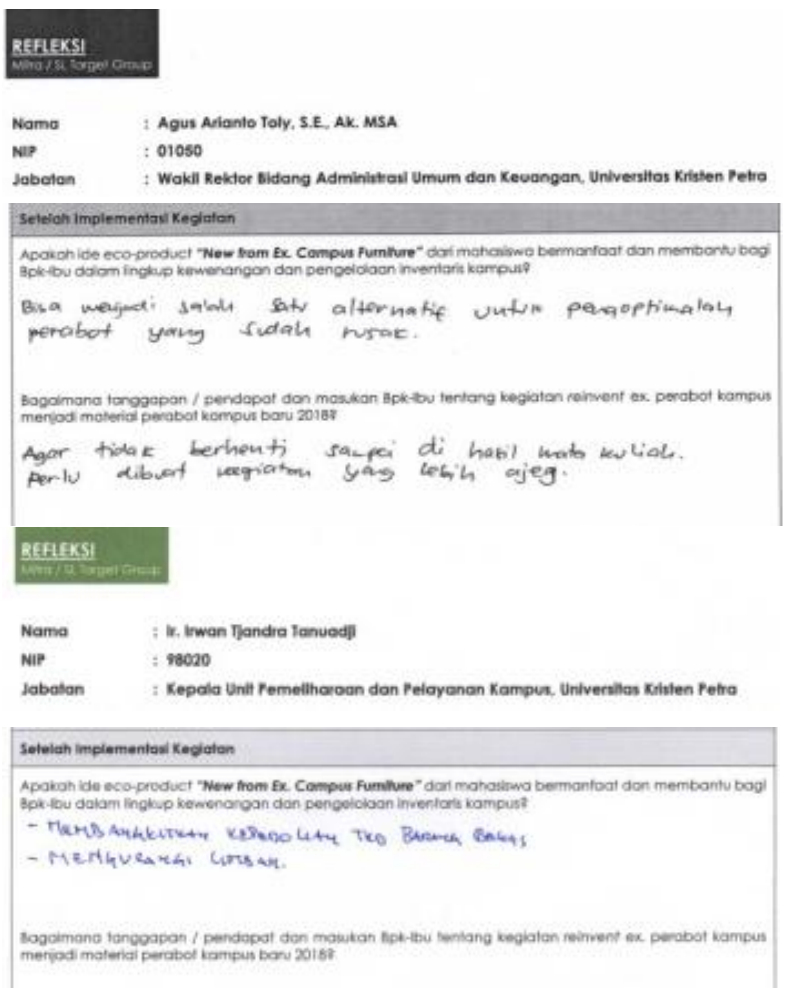

Gambar 6. Refleksi dari Mitra UPPK dan Wakil Rektor 2

Mitra berharap mahasiswa dapat memberikan inovasi produk baru yang bermanfaat, sehingga mahasiswa juga ikut berperan aktif dalam kepedulian untuk mengurangi limbah dan memberikan alternatif pengoptimalan perabot yang telah rusak.

\section{SIMPULAN}

Setelah pelaksanaan Mata Kuliah Eko-Desain 2018, berikut simpulan yang dapat dikemukakan;

1. Mata Kuliah Eko Desain mengumpulkan solusi kreatif desain terkait masalah ex-perabot di gudang perbekalan UPPK dengan menerapkan pendekatan metode service learning dan design thinking. Tahapan-tahapan yang dilalui ada eksplorasi yang berupa pengenalan teori, wawancara dan observasi kebutuhan pengguna serta material ex-perabot, ideasi yaitu mencari ide solusi kreatif desain yang dapat menjawab masalah tersebut, realisasi produk yang mana mewujudkan ide solusi desain, evaluasi produk oleh mitra kampus dan refleksi mendalam yang diberikan untuk mahasiswa dan mitra kampus.

2. Solusi desain Mata Kuliah Eko-Desain mahasiswa angkatan 2016 adalah enam kelompok membuat fasilitas duduk, delapan kelompok membuat fasilitas tempat storage, dua kelompok membuat fasilitas duduk beserta meja, dua kelompok membuat fasilitas aksesoris lampu, satu kelompok membuat fasilitas meja, satu kelompok membuat fasilitas trolly, dan satu kelompok membuat fasilitas lampu dan storage.

Produk-produk dari mahasiswa yang dapat memenuhi standar dikelompokan dalam:

a. Produk yang fungsinya menjawab kebutuhan masyarakat Universitas Kristen Petra secara maksimal berjumlah 11 kelompok,

b. Produk yang fungsinya baik, tetapi kurang menjawab kebutuhan masyarakat Universitas Kristen Petra berjumlah tujuh kelompok,

c. Produk yang dihasilkan fungsinya belum menjawab kebutuhan masyarakat Universitas Kristen Petra berjumlah dua kelompok.

3. Pembelajaran yang didapat dari kegiatan Service Learning Eko-Desain 2018 adalah mahasiswa tidak hanya meningkatkan hardskill seperti pemahaman teori dan analisa kebutuhan saja tetapi soft skill juga digali dalam proses pembelajaran ini, yaitu mahasiswa diajak untuk berinteraksi langsung dengan Mitra UPPK, Mitra Kampus dan tukang.

\section{UCAPAN TERIMAKASIH}

Projek service-learning yang dilaksanakan dalam proses pembelajaran Mata Kuliah Eko-Desain 2018 ini adalah bagian dari projek penelitian yang didanai oleh Direktorat Riset dan Pengabdian Masyarakat, Direktur Jenderal Penguatan Riset dan Pengembangan, Kementerian Riset, Teknologi, dan Pendidikan Tinggi Nomor: 120/SP2H/LT/ DRPM/2018. Skema hibah yang didanai adalah Penelitian Dasar Unggulan Perguruan Tinggi 2018 dengan judul "Model Pembelajaran Sustainable Design Dengan Metode Service Learning Sebagai Upaya Meminimalkan Celah Teori Dan Praktik”. Berkat dukungan tersebut, kegiatan dapat terlaksana dengan baik, dan oleh karenanya diucapkan terimakasih.

\section{DAFTAR PUSTAKA}

Ciwendro,C. 2014. Kajian Terapan Eko-Interior Pada Objek Rancangan Bangun Karya Baskoro Tedjo. Dimensi Interior. 12(1): 7. 
Fuad-Luke. 2004. The Eco-Design Handbook: Complete Sourcebook for the Home and Office Hardcover.2 (Second), Eastbourne-UK.

Nusanti,I. 2014. Strategi Service Learning Sebuah Kajian Untuk Mengembangkan Kegiatan Pembelajaran. Pendidikan Dan Kebudayaan. 20(2): 253-254.
Kusumarini, Y, Agus S, Budi I. 2007. Kajian Terapan Eko-Interior pada Bangunan Berwawasan Lingkungan Rumah Dr. Heinz Frick di Semarang; Kantor PPLH di Mojokerto; Perkantoran Graha Wonokoyo di Surabaya. ITB J.Vis.Art. 1D (2): 280,282-283. 